\title{
Are Consumers Ready for Augmented Reality? Factors Influencing Online Footwear Purchasing Intentions Using AR Technology
}

\author{
Claudio Schapsis \\ Nebraska Wesleyan University \\ Larry Chiagouris \\ Pace University \\ Ngoc Cindy Pham \\ Brooklyn College
}

Some online retailers flourished during the COVID-19 pandemic time. Apparel retailers face the dilemma of how to adapt a considerable part of their businesses to mobile commerce. Augmented Reality (AR) applications offer the capability to try clothing and footwear items virtually. We address critical factors for consumers to adopt AR to shop apparel in general and footwear in particular. Based on a real-life pilot, we present six Research Propositions that can be addressed in future research and introduce a novel approach to evaluate the UTAUT2 constructs that result in a new way to view Habit and Price Value often ignored in extant research.

Keywords: augmented reality, m-commerce, MAR, retail, UTAUT, mobile shopping, consumer behavior, $A R$

\section{INTRODUCTION}

The COVID-19 pandemic emerged in Wuhan, China, in December 2019, and in a matter of a few months, the world changed dramatically. Strict quarantine rules like those implemented by Italy and Greece and laxer policies in the US came with consequences for retailers.

Retail stores selling apparel and footwear suffered considerable declines, more significantly those not prepared to offer a seamless online experience. Nevertheless, that was enough to have retailers like Kohl's, T.J. Maxx, Marshalls, Gap Inc., H\&M, Macy's, and Bloomingdale's, to name a few, to close their physical stores across the U.S. temporarily (Testa, Maheshwari, \& Friedman, 2020). Other retailers. i.e., Neiman Marcus, Brooks Brothers, J.C. Penney Co., and mall owners like CBL \& Associates Properties Inc. and Pennsylvania Real Estate Investment Trust had to file for chapter 11 bankruptcy protection, a consequence of their loss of revenues (Fung, 2020).

A study conducted by McKinsey \& Company (2020) paints a bleak picture for apparel and footwear retailers. According to their global April-May 2020 COVID-19 Consumer Pulse survey, categories like groceries, home entertainment, and household products gained in consumer purchasing net intent, but 
categories such as apparel and footwear suffered a decline to over $-50 \%$. Simultaneously, the number of consumers who expect to shift part of their apparel and footwear to digital stores grew in a range of $15 \%$ to 29\% (ibid). Furthermore, BDO (2020) reports that by mid-2020, from 29 chapter 11 bankruptcy filings, 13 were Apparel/Footwear brands and department stores.

For traditional retailers struggling to stay afloat during the quarantine times, Augmented Reality can recreate a real-world shopping experience in the virtual world.

As consumers are willing to shop more online, Augmented Reality (AR) is listed as one of the top technological solutions that may allow them to evaluate online merchandise (Tavolieri, 2019) and "help them recreate the real-world shopping experience in the virtual world" (Conger, 2020). Consequently, companies like Amazon are now implementing Artificial Intelligence algorithms to try different outfits virtually [7]. Another example of a brand turning to AR is Gucci, which in the middle of the pandemic closures, released together with Snap Inc., the capability to virtually try the brand shoes on snapchat and purchase them with a click of a button (Hirschmiller, 2020; A. Lee, 2020).

A large stream of research tried to identify who the online apparel shoppers are. However, those studies focused on people that were already purchasing online. The current preponderantly-remote/online modality of shopping requires a different set of questions that should be analyzed to determine under which circumstances consumers will be open to using online-only tools to buy such products (Javornik, 2016).

The issue at hand is to understand if consumers are ready to virtually try relatively expensive apparel items and be open to purchase them even if they cannot touch the actual product. It is essential to note, at this point, the difference between mobile AR (MAR) applications and those virtual dressing rooms (magic mirrors) that some retailers already tried (Javornik, Rogers, Moutinho, \& Freeman, 2016). The critical difference is that while at the store, the consumer can virtually try many items and select one. Still, in that case, the consumer can reevaluate the transaction when the product is placed in its hands (Boardman, Henninger, \& Zhu, 2020). Contrary, in the case of AR at-home purchases, customers must pay and wait for a delivery to touch the product. The purchase decision is taken at different stages, making the first one less risky.

Based on widely accepted technology acceptance models, our paper tries to identify critical antecedents to Augmented Reality's adoption for online apparel shopping and proposes research questions based on a limited pilot conducted in October 2020.

\section{BACKGROUND TO THE RESEARCH}

\section{Understanding Augmented Reality}

In laymen's terms, Augmented Reality is a technology that allows a person to observe the real world through a see-through device and, at the same time, observe objects added to that real-world environment. $\mathrm{AR}$ is a technology that comprises three key elements: It combines in a) real-time and interactively b) realworld physical view, and c) it is registered in three dimensions (Azuma, 1997; Van Krevelen \& Poelman, 2010; Yaoyuneyong, Foster, Johnson, \& Johnson, 2016; Zhou, Duh, \& Billinghurst, 2008). "Registered," in this context, means the capability to seamlessly align virtual objects with the real world (Papagiannis, 2017), i.e., if a user looks at his room through a mobile device camera and places virtual furniture, that furniture will show in the correct size. These three components make the difference between AR and other types of Mixed Realities (MR), such as Augmented Virtuality (AV), which combines real elements in a virtual world, and Virtual Reality (VR) that immerses the individual in an all-virtual environment. AR has been used and studied across industries, i.e., AEC (Chi, Kang, \& Wang, 2013; Piroozfar, Farr, Boseley, Essa, \& Jin, 2018), education (Akçayır \& Akçayır, 2017; Altinpulluk, 2019; P. Chen, Liu, Cheng, \& Huang, 2017), gaming (Von Itzstein, Billinghurst, Smith, \& Thomas, 2019), healthcare (Ferrari, Klinker, \& Cutolo, 2019; Gerup, Soerensen, \& Dieckmann, 2020), Real Estate (Lang \& Sittler, 2012), travel/tourism (Kečkeš \& Tomičić, 2017; Yung \& Khoo-Lattimore, 2019) and to the topic of this paper marketing (Bulearca \& Tamarjan, 2010; Scholz \& Duffy, 2018; Wedel, Bigné, \& Zhang, 2020) 


\section{AR and Marketing Applications}

One of the first use cases of AR marketing application mentioned in the literature is the campaign conducted by MINI, where a user pointing a mobile device at a printed ad could see the car coming out of the page in 3d (Carmigniani \& Furht, 2011). Javornik (2014) looked into AR as a tool that offers new capabilities to enhance consumers' experiences through direct interaction and brand engagement through advertising, product customization, virtual product tryouts, and customer service, to name a few. In other words, Augmented Reality Marketing (ARM) "focuses on creating digital affordances for customer experiences, which are the digital cues in a physical environment designed to scaffold (i.e., assist) customer actions and experiences." (Chylinski et al., 2020)

Those customer actions and experiences predominantly happen nowadays through their mobile devices. Customers are always connected and carry their mobile devices everywhere they go, and that they are using these devices to sense, experience, and record the world (Schapsis \& Chiagouris, 2019). Therefore, ARM allows marketers to engage customers with relevant and within-context information to enhance consumers' shopping experience, i.e., showing consumers how they would look wearing a specific product (Parise, Guinan, \& Kafka, 2016). Pokemon Go is an excellent example of user engagement through AR that caught comprehensive media coverage and significant academic research (Hamari, Malik, Koski, \& Johri, 2019; Kim, Kim, \& Song, 2019; Pamuru, Khern-am-nuai, \& Kannan, 2020; Wu, 2017).

With the proliferation of e-commerce, retailers saw a real benefit in implementing AR capabilities to their stores, websites, and apps (Cruz et al., 2019). A quick online search of "eyewear virtual try on" shows that most large eyewear retailers with online presence such as LensCrafters and Warby Parker, eyewear eretailers such as glasses.com, glassesusa.com, eyeconic.com, and lingo.com, to name a few, and brands like Armani, Burberry, Oakley, Ray-Ban, and others have implemented glasses and frames virtual try-on AR features on their online presence. Substantial research has been done on how AR influence customer decisions when purchasing eyewear (Pantano, Rese, \& Baier, 2017; Poushneh \& Vasquez-Parraga, 2017a, 2017b; Roxo \& Brito, 2019).

Using AR in different applications, brands such as Burberry, L'Oréal, Mac Cosmetics, Rebecca Minkoff, Uniqlo, and others have tested in-store AR mirrors (Caboni \& Hagberg, 2019).

Furthermore, leading brands selling furniture such as IKEA and Wayfair had implemented AR as part of their mobile app (Scholz \& Duffy, 2018). These MAR applications allow customers to visualize a piece of furniture in their room before deciding to purchase an item (H. Lee \& Leonas, 2018; Marr, 2019).

Nevertheless, while by many standards, AR is becoming one of the emerging trends in mobile marketing (Narang \& Shankar, 2019), for the most part, customers "are still uncertain about the value of AR" (de Ruyter et al., 2020). Hence, the importance of reviewing and analyzing the antecedents that will help customers accept and incorporate MAR as part of their mobile shopping experience.

\section{Conceptual Framework}

Wiebach and Send (2020) argue that "gauging customer acceptance is of vital importance to determine which role AR can play in the retail market." Venkatesh, Morris, Davis, and Davis (2003) presented an extended Unified Theory of Acceptance and Use of Technology (UTAUT) based on eight different known technology acceptance models. UTAUT was extensively used to understand mobile consumer behavior and was later expanded to a UTAUT2 model by Venkatesh, Thong, and Xu (2012) to analyze the use of technology in a consumer context by incorporating three constructs, i.e., hedonic motivation, price value, and habit.

This paper intends to formulate critical questions regarding consumer intent to use AR for shopping purposes and not to revalidate the whole UTAUT2 model. Hence, a reduced model with the relevant constructs was operationalized. We aimed to examine users' behavioral intentions to adopt AR for apparel shopping with the specific purpose of validating the methodology and formulating new research questions. 
FIGURE 1

THE RESEARCH MODEL

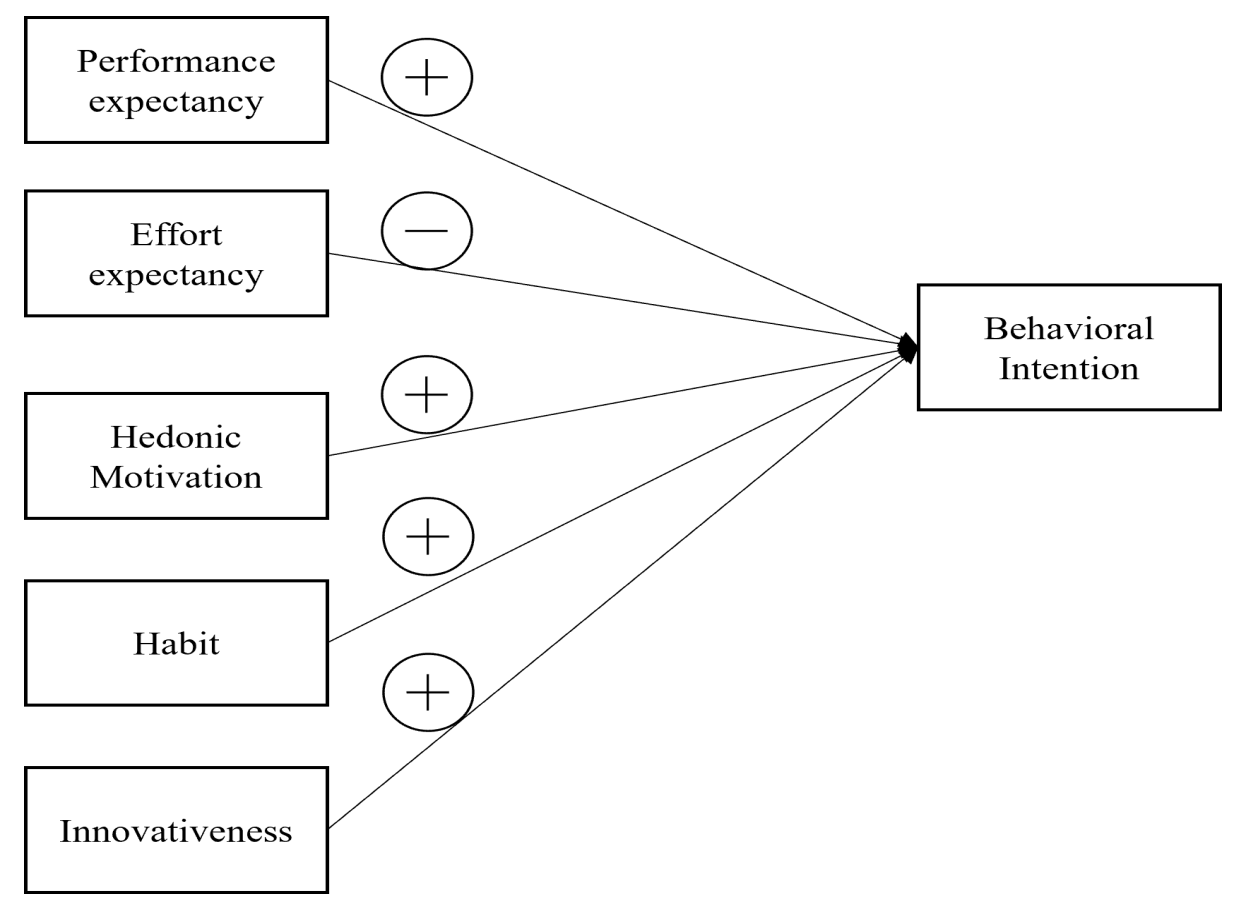

Following the UTAUT, we expected the following:

H1: The higher the Performance Expectancy (PE), the higher the Behavioral Intention (BI) to adopt MAR apps for apparel shopping.

H2: When the users' Effort Expectation (EE) increases, the BI will decrease.

H3: Users with higher Hedonic Motivation (HM) will show higher BI.

H4: Users that habitually use AR in their mobile devices $(H)$ will show higher BI.

H5: Users that display higher Innovativeness (I) will display higher BI.

\section{METHODOLOGY}

\section{AR Apps as Stimulus Research Tools}

Due to AR's experiential and immersive nature (Huang, Chen, \& Chou, 2016), it is often required to use existing AR apps and expose the study subjects to experiment with how AR works. Following the same concept used by Cho and Kim (2019), McLean and Wilson (2019), Pantano et al. (2017), and others, of using an existing commercial app, this research employed a free app available for iOS and Android devices. The participants were required to download and install the free app called "Wanna Kicks." The app has a straightforward interface. The participants were informed ahead of time that they were not required to buy anything in the app to participate in the survey. Once the app users point the camera towards their feet, the app's AR functionality will recognize the feet and show them the selected shoes as if they were wearing them (See Figure 2).

Participants were asked to explore the app AR functionality, choose a pair they like, and take a picture of their feet with a pair of shoes to share as part of the survey. 


\section{FIGURE 2 \\ USERS' VIEW OF THE SHOES IN AR}
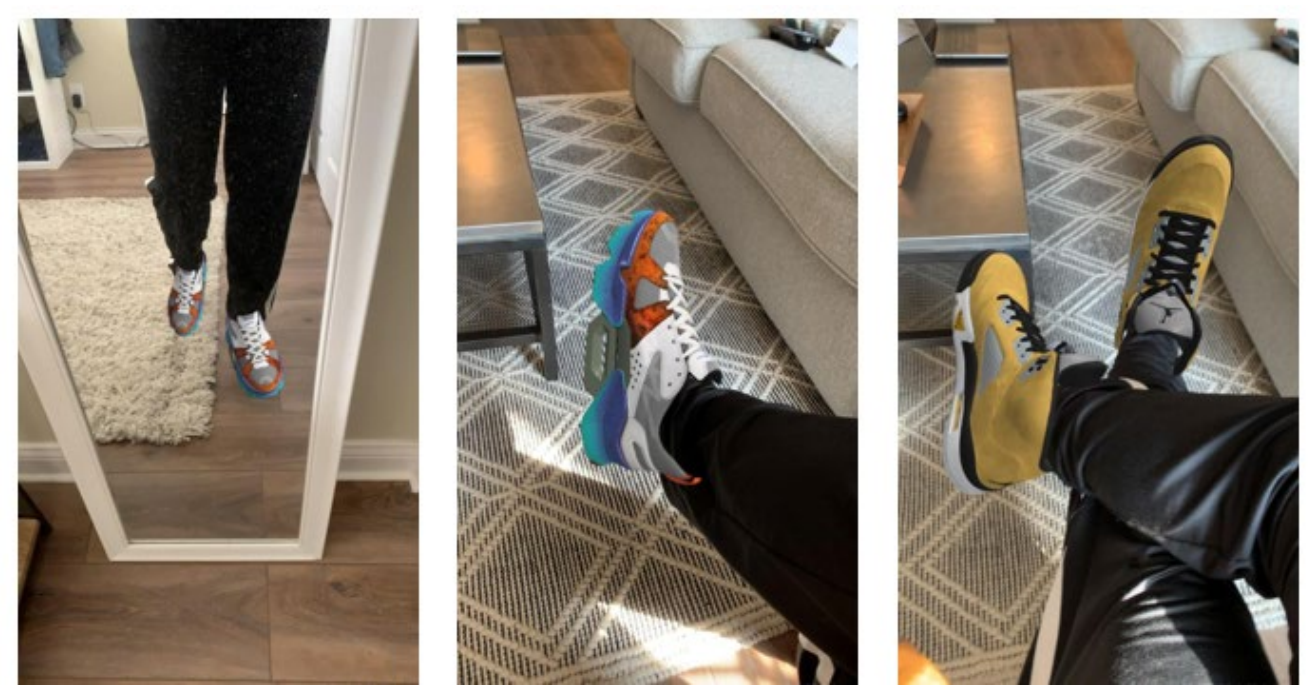

\section{Data Collection}

A total of 350 individuals completed the survey for a nominal fee via mTurk. Kees, Berry, Burton, and Sheehan (2017) conducted a study comparing different samples in advertisement experiments and found that "MTurk data outperformed panel data procured from two separate professional marketing research companies across various measures of data quality." While this is a relatively new form of collecting research data (Xiao, Yun, \& Yueqing, 2019), we followed accepted best practices. For example, Feitosa, Joseph, and Newman (2015) recommend restricting answers to subjects located in native-English countries. Consistent with Zhang and Barnes (2019), the surveys to collect data for this study were shown only to individuals in the US. Furthermore, Smith, Roster, Golden, and Albaum (2016) identify two types of unreliable mTurk individuals "cheaters" and "speeders." They define cheaters as "a respondent who intentionally answers survey questions dishonestly and in a fashion that maximizes their opportunity for participation and subsequent rewards." (Smith et al., 2016). In the case of this study, users had to submit a picture of their feet wearing a virtual show as a screen capture of the app.

Additionally, Smith et al. (2016) characterize a mTurk speeder as "a respondent who does not thoroughly read the questions and uses minimal cognitive effort to provide answers that satisfy the question." Following their recommendation, our survey included filter questions. After considering the safeguards mentioned above, 213 were included in our study. Demographic details of the sample can be found in Table 1.

\section{Measures}

The questioner used in this research was mainly adapted from Venkatesh et al. (2012) UTAUT with 7point Likert Scale. The questionnaire included 23 questions in 6 constructs, Performance Expectancy (PE), Hedonic Motivation (HM), Habit using AR (H), Effort Expectancy (EE), Innovativeness (I), and Behavioural Intention (BI)

The survey was distributed using Qualtrics, and data was collected from a mTurk group from the end of October 2020 to the first week of November 2020. As mentioned, the items on the questioner were based on a widely used inventory developed by Venkatesh et al. (2012) with some adaptations made to the UTAUT items inventory to consider elements of mobile shopping (Celik, 2016; Chiu, Lin, Sun, \& Hsu, 2009; Pappas, Pateli, Giannakos, \& Chrissikopoulos, 2014), mobile gaming (Ramírez-Correa, RondánCataluña, Arenas-Gaitán, \& Martín-Velicia, 2019), mobile banking (Sarfaraz, 2017), and Augmented Reality (Paulo, Rita, Oliveira, \& Moro, 2018). 


\section{RESULTS}

\section{Model Specification}

We categorized 23 survey questions into six constructs studied in our conceptual model (Figure 1). The exploratory factor analysis (Table 2) shows that the six constructs PE, HM, H, EE, I, and BI are unique as their alpha values are close to 1 .

Table 3, "reliability, validity statistics and correlations," shows that the diagonal elements (in bold $\dagger$ ) range from 0.77 to 0.87 and are higher than the various AVE values that range from 0.593 to 0.756 , indicating the adequate discriminant validity of the model's constructs. Moreover, the chi-square test, the Comparative Fit Index, the Standardized Root Mean Square Residual test, Root Mean-Square Error of Approximation test, and the p-value of the null hypothesis test all indicate that our structural equation model fits well within the accepted thresholds (see Table 4 - Fit indices of CFA model).

\section{Pilot's Structural Model}

As indicated by the standardized path coefficients in Table 5 and Figure 3, we can see a positive and significant relationship between Performance Expectancy and Behavioural Intention $(b=0.530, p=0.000)$. Thus, H1 is supported. The relationship between Effort Expectancy and Behavioral Intention is negative but not statistically significant $(b=-0.035 \mathrm{p}=0.572$ ). Therefore, $\mathrm{H} 2$ is not supported. Although Hedonic Motivation and Behavioral Intention's relationship is positive, it was not statistically significant $(b=0.079$, $\mathrm{p}=0.298$ ). Hence, $\mathrm{H} 3$ is not supported. Moreover, we find that Habit and Behavioral Intention's relationship is positive and significant $(b=0.236, p=0.000)$. Thus, $\mathrm{H} 4$ is supported. Furthermore, there is a positive and significant relationship between Innovativeness and Behavioral Intention $(b=0.249, p=0.000)$. Therefore, H5 is supported. Finally, we find that Performance Expectancy ranks as the number 1 significant factor to influence consumers' Behavioral Intention $(b=0.530, p=0.000)$, Innovativeness as the number 2 significant factor $(b=0.249, p=0.000)$, and Habit as the number 3 significant factor $(b=0.236, p=0.000)$.

FIGURE 3

\section{RESEARCH MODEL AND RESULTS}

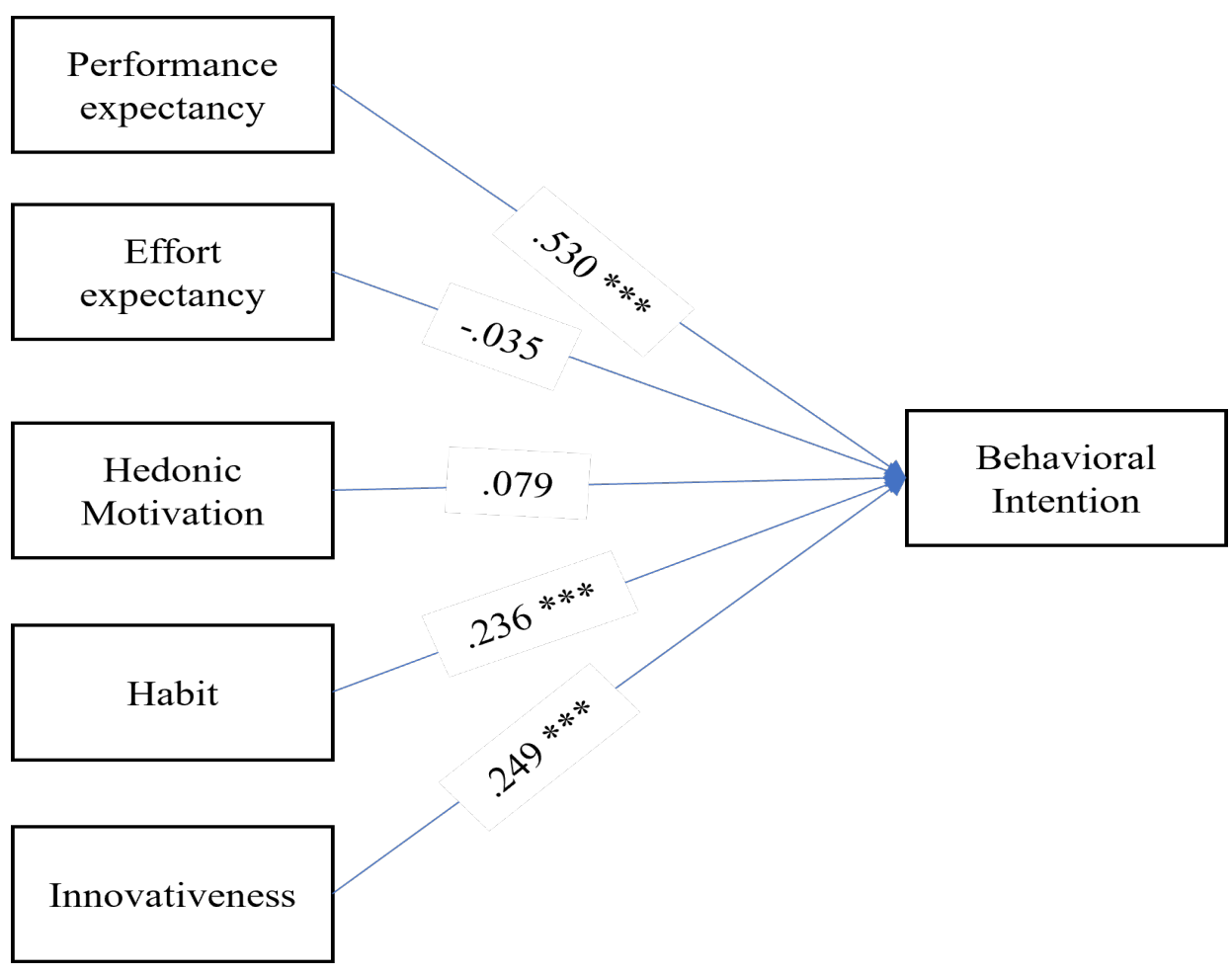




\section{DISCUSSION, IMPLICATIONS, AND CONCLUDING REMARKS}

By examining the results, it is possible to identify two types of constructs' antecedents for Behavioral Intention to use AR to purchase apparel. The first happens when the consumer is exposed to the AR mobile shopping app. In other words, the users' Performance Expectancy, Hedonic Motivation, and Effort Expectancy are directly related to the fact that the user is using an AR-based mobile shopping application, i.e., in the absence of such mobile app, those constructs will not be manifested. The second type of antecedents for Behavioral Intention to use AR constructs were present before the subjects were exposed to the AR application.

\section{Constructs That Manifest Themselves When the Technology Is Used}

This study's empirical findings suggest that Performance Expectancy is the crucial factor for consumers to adopt AR for apparel shopping. In other words, different from other applications of AR, i.e., mobile games (Harborth \& Pape, 2017; Ramírez-Correa et al., 2019), effectiveness and usefulness are the key motives driving consumer intention to use AR for apparel shopping purposes. Moreover, different from extant mobile commerce research (Kiseol \& Forney, 2013; Shaw \& Sergueeva, 2019; Tak \& Panwar, 2017), this study data suggests that Hedonic Motivation plays no significant role in the consumer intention to use AR for mobile apparel shopping purposes.

Therefore, the following research propositions can be formulated.

RP1: Performance Expectancy positively influences the user intention to use AR for apparel mobile shopping purposes.

RP2: Hedonic Motivation plays no role in the user intention to use AR for apparel mobile shopping purposes.

Data also suggest that Performance Expectancy is by far the most critical factor affecting users' intention. Therefore, it can be proposed that:

RP3: Performance Expectancy is the most critical factor that drives user intention to use AR for apparel mobile shopping purposes.

\section{Constructs That Exist Before the Technology Is Used}

Habit and the Innovativeness nature of the user preceded the user exposure to the specific shopping app. Habit was a significant predictor in our model. Since Habit is one of the least studied constructs in the UTAUT context (Tamilmani, Rana, \& Dwivedi, 2018), special attention is required. However, in the case of AR for mobile shopping, different types of habits can be identified. Consumers may already have a habit of shopping online. Additionally, users may have a habit of using AR in other contexts, for example, filters in applications such as Instagram, TikTok, Snapchat, and others. Therefore, we propose that Habit should be divided into specific habit treats:

RP4: Online Shopping Habit positively influences the user intention to use AR for apparel mobile shopping purposes.

RP5: AR Usage Habit positively influences the user intention to use AR for apparel mobile shopping purposes.

Furthermore, we foresee that those pre-existing constructs will influence the relationship between the "at exposure" constructs and the Behavioral Intention. Therefore, we consider it wise to explore how the relationship between Performance Expectancy and users' Behavioral Intention to use AR for apparel mobile 
shopping purposes is moderated by the users' different related habits such as online shopping habits and AR usage habits.

\section{Other UTAT Constructs That May Be Adapted to Study AR and Shopping}

One of the UTAUT2 consumer-oriented constructs omitted in this pilot was Price Value. Venkatesh et al. (2012) define Price Value as "consumers' cognitive tradeoff between the perceived benefits of the applications and the monetary cost for using them."

Price Value is usually omitted in consumer mobile technology adoption as those users usually do not pay to use that technology (Tamilmani, Rana, Dwivedi, Sahu, \& Roderick, 2018), i.e., they do not pay for the app. That may be different from some mobile games where the user pays for the app or premium content (Ramírez-Correa et al., 2019). Shaw and Sergueeva (2019) assert that Price Value is irrelevant in the case of m-commerce and should be substituted by a more appropriate construct, "Perceived Value." The definition and analysis of this construct were beyond our pilot's scope. Nevertheless, and consistent with extant research, we can propose that:

RP6: Perceived Value positively influences the user intention to use AR for apparel mobile shopping purposes.

\section{Relevance to the Academic Marketing Discipline}

Drawing concepts from the extended Unified Theory of Acceptance and Use of Technology (UTAUT2,) this research evaluates critical initial constructs that may affect consumers' behavioral intentions to use Augmented Reality (AR) for apparel shopping, specifically when purchasing products in the form of sports footwear.

Most of the current stream of research on AR in marketing focuses on AR applications that add context and information to the external user's environment, i.e., placing furniture in a room, showing complementary product data, augmenting information to places, to name a few. Our research investigates how customers may use AR to "see and try" the products on themselves. Moreover, our study focuses on online purchases, differing from magic mirror AR applications in brick and mortar stores.

This paper presents a novel approach to review the concept of Habit and its relationship to AR-based apparel $\mathrm{m}$-commerce.

Furthermore, our research propositions call for a new view of the UTAUT2 constructs. We propose differentiating the UTAUT 2 constructs into two main categories; those that manifest themselves when the user is exposed to the technology in question and those that can be considered "pre-existing conditions."

Furthermore, we propose that those pre-existing conditions may affect the users' behavioral intentions and, at the same time, moderate the relationships of factors that occur when the user is exposed to the technology itself.

\section{Relevance to Marketing Practitioners}

This research will be of high interest to brands and retailers with an m-commerce presence. Although the current study is highly relevant to the apparel and footwear industries, its relevance is much more extensive. Jewelry, athletic equipment, and even fashion accessories sectors, to name a few, have the potential to benefit substantially from AR.

Though some retailers suffered considerable revenue declines during the closures imposed as preventive measures due to the COVID-19 pandemic, and while many of them had online shopping stores in place, they needed to adapt to customers who did not purchase online apparel and footwear before. This capability to use technology to create enhanced marketing activities that satisfy consumer needs is a key for business success (H.-c. Chen, Sun, \& Chen, 2020). Also, they need to consider that customers face additional challenges when the "showrooming" option (see in-store/buy online) is not available anymore. This research will help retailers better segment the market to target the right customers with the right products using AR applications to bring the consumer to a final purchase. Moreover, this research will be 
of high interest to advertising professionals to understand customer's attitudes towards AR, as AR ads are already being deployed in social networks like Facebook, Instagram, Snapchat, TikTok, and others.

\section{Closing Remarks}

In conclusion, this pilot study shows that Performance Expectancy, Innovativeness, and Habit significantly affect consumers' intentions to use AR for apparel shopping online. We observed that users' intentions to use AR highly depend on the AR system's performance and utility. Furthermore, the customers' innovative character and digital habits may determine if they will adopt this type of technology.

Thus, online apparel retailers should focus on developing and deploying AR systems that add value and facilitates the customers' purchasing process. They should also keep in mind that it might be easier to attract habitual online shoppers and individuals already familiar with AR in other contexts, such as social media face filters.

Considering that the utility derived from the AR shopping mobile app is critical for this technology adoption, of no less importance is the hedonic motivation and effort expectancy lack of relevance found in our pilot. Our research propositions address this departure from the UTAUT2 model and recommend further investigation to understand if gamification or the fun factor plays any role in consumers' behavioral intentions when purchasing apparel using AR applications. In other words, it is essential to understand if pleasure and enjoyment derived from using these platforms are stemmed from the usage itself or from the utilitarian benefits the user will obtain.

\section{REFERENCES}

Akçayır, M., \& Akçayır, G. (2017). Advantages and challenges associated with augmented reality for education: A systematic review of the literature. Educational Research Review, 20, 1-11.

Altinpulluk, H. (2019). Determining the trends of using augmented reality in education between 20062016. Education and Information Technologies, 24(2), 1089-1114.

Azuma, R.T. (1997). A survey of augmented reality. Presence: Teleoperators \& Virtual Environments, $6(4), 355-385$.

BDO. (2020). Retail in the Red: BDO Bi-Annual Bankruptcy Update - An Overview of U.S. Retail Bankruptcies and Store Closures in the first half of 2020. Retrieved from https://www.www.bdo.com/insights/industries/retail-consumer-products/retail-in-the-red-bdo-biannual-bankruptcy-upd-(4)

Boardman, R., Henninger, C.E., \& Zhu, A. (2020). Augmented reality and virtual reality: New drivers for fashion retail? In Technology-Driven Sustainability (pp. 155-172). Springer.

Bulearca, M., \& Tamarjan, D. (2010). Augmented reality: A sustainable marketing tool. Global Business and Management Research: An International Journal, 2(2), 237-252.

Caboni, F., \& Hagberg, J. (2019). Augmented reality in retailing: A review of features, applications and value. International Journal of Retail \& Distribution Management, 47(11), 1125-1140. doi:10.1108/IJRDM-12-2018-0263

Carmigniani, J., \& Furht, B. (2011). Augmented reality: An overview. In Handbook of augmented reality (pp. 3-46). Springer.

Celik, H. (2016). Customer online shopping anxiety within the Unified Theory of Acceptance and Use Technology (UTAUT) framework. Asia Pacific Journal of Marketing and Logistics, 28(2), 278307.

Chen, H-C., Sun, S-Y., \& Chen, L-S. (2020). The Impact of E-Commerce Firms' Capabilities on Value Offering in the Online Shopping Environment. Journal of Marketing Development \& Competitiveness, 14(1).

Chen, P., Liu, X., Cheng, W., \& Huang, R. (2017). A review of using Augmented Reality in Education from 2011 to 2016. In Innovations in smart learning (pp. 13-18). Springer. 
Chi, H-L., Kang, S-C., \& Wang, X. (2013). Research trends and opportunities of augmented reality applications in architecture, engineering, and construction. Automation in Construction, 33, 116122.

Chiu, C-M., Lin, H-Y., Sun, S-Y., \& Hsu, M-H. (2009). Understanding customers' loyalty intentions towards online shopping: An integration of technology acceptance model and fairness theory. Behaviour \& IT, 28, 347-360. doi:10.1080/01449290801892492

Cho, S.H., \& Kim, C.S. (2019). Consumer Attitudes, Intention to Use Technology, Purchase Intention of Korean 20's Women on the Acceptance of Fashion Augmented Reality (FAR) with the Application of the UTAUT Model. Journal of the Korean Society of Clothing and Textiles, 43(1), 125-137.

Chylinski, M., Heller, J., Hilken, T., Keeling, D. I., Mahr, D., \& de Ruyter, K. (2020). Augmented reality marketing: A technology-enabled approach to situated customer experience. Australasian Marketing Journal (AMJ).

Conger, K. (2020, December 22). Does the Shoe Fit? Try It On With Augmented Reality. Retrieved from https://www.nytimes.com/2020/12/22/technology/augmented-reality-online-shopping.html

Cruz, E., Orts-Escolano, S., Gomez-Donoso, F., Rizo, C., Rangel, J.C., Mora, H., \& Cazorla, M. (2019). An augmented reality application for improving shopping experience in large retail stores. Virtual Reality, 23(3), 281-291.

de Ruyter, K., Heller, J., Hilken, T., Chylinski, M., Keeling, D.I., \& Mahr, D. (2020). Seeing with the customer's eye: Exploring the challenges and opportunities of AR advertising. Journal of Advertising, 49(2), 109-124.

Feitosa, J., Joseph, D.L., \& Newman, D.A. (2015). Crowdsourcing and personality measurement equivalence: A warning about countries whose primary language is not English. Personality and Individual Differences, 75, 47-52. doi:https://doi.org/10.1016/j.paid.2014.11.017

Ferrari, V., Klinker, G., \& Cutolo, F. (2019). Augmented Reality in Healthcare. Journal of Healthcare Engineering.

Fung, E. (2020, November 20). Malls File for Bankruptcy or Shut Their Doors as Pandemic Pain Spreads. Retrieved from https://www.wsj.com/articles/malls-file-for-bankruptcy-or-shut-theirdoors-as-pandemic-pain-spreads-11605013664

Gerup, J., Soerensen, C.B., \& Dieckmann, P. (2020). Augmented reality and mixed reality for healthcare education beyond surgery: An integrative review. International Journal of Medical Education, $11,1$.

Hamari, J., Malik, A., Koski, J., \& Johri, A. (2019). Uses and gratifications of pokémon go: Why do people play mobile location-based augmented reality games? International Journal of HumanComputer Interaction, 35(9), 804-819.

Harborth, D., \& Pape, S. (2017). Exploring the hype: Investigating technology acceptance factors of Pokémon Go. Paper presented at the 2017 IEEE International Symposium on Mixed and Augmented Reality (ISMAR).

Hirschmiller, S. (2020, June 29). Gucci's New Snapchat Filters Let Users Try \& Buy Sneakers Virtually - What This Could Mean for Facebook. Retrieved from

https://footwearnews.com/2020/business/marketing/guccis-snapchat-filters-virtually-try-sneakerswhat-mean-for-facebook-1203014353/

Huang, T-C., Chen, C-C., \& Chou, Y-W. (2016). Animating eco-education: To see, feel, and discover in an augmented reality-based experiential learning environment. Computers \& Education, 96, 72 82.

Javornik, A. (2014, September 10-12). [Poster] classifications of augmented reality uses in marketing. Paper presented at the 2014 IEEE International Symposium on Mixed and Augmented Reality Media, Art, Social Science, Humanities and Design (ISMAR-MASH'D).

Javornik, A. (2016). Augmented reality: Research agenda for studying the impact of its media characteristics on consumer behaviour. Journal of Retailing and Consumer Services, 30, 252261.

30 Journal of Marketing Development and Competitiveness Vol. 15(2) 2021 
Javornik, A., Rogers, Y., Moutinho, A.M., \& Freeman, R. (2016). Revealing the shopper experience of using a" magic mirror" augmented reality make-up application. Paper presented at the Conference on designing interactive systems.

Kečkeš, A.L., \& Tomičić, I. (2017). Augmented reality in tourism-research and applications overview. Interdisciplinary Description of Complex Systems: INDECS, 15(2), 157-167.

Kees, J., Berry, C., Burton, S., \& Sheehan, K. (2017). An Analysis of Data Quality: Professional Panels, Student Subject Pools, and Amazon's Mechanical Turk. Journal of Advertising, 46(1), 141-155. doi:10.1080/00913367.2016.1269304

Kim, D.H., Kim, S., \& Song, D. (2019). Can Pokémon GO catch brands? The fit effect of game characters and brands on efficacy of brand communications. Journal of Marketing Communications, 25(6), 645-660.

Kiseol, Y., \& Forney, J.C. (2013). The moderating role of consumer technology anxiety in mobile shopping adoption: Differential effects of facilitating conditions and social influences. Journal of Electronic Commerce Research, 14(4), 334-347. Retrieved from http://proxy.library.nyu.edu/login?url=http://search.ebscohost.com/login.aspx?direct=true\&db=ac i\&AN=95999589\&site $=$ eds-live

Lang, V., \& Sittler, P. (2012). Augmented reality for real estate. Paper presented at the Research Paper, 18th Pacific-RIM Real Estate Society (PRRES) Conference, Adelaide, Australia.

Lee, A. (2020, June 29). Gucci Reveals Snapchat AR Shoe Try-ons. Retrieved from https://wwd.com/business-news/technology/gucci-reveals-snapchat-ar-shoe-try-ons-1203661812/

Lee, H., \& Leonas, K. (2018). Consumer experiences, the key to survive in an omni-channel environment: Use of virtual technology. Journal of Textile and Apparel, Technology and Management, 10(3).

Marr, B. (2019). The 10+ Best Real-World Examples of Augmented Reality. Retrieved from https://www.forbes.com/sites/bernardmarr/2019/03/01/the-10-best-real-world-examples-ofaugmented-reality/

McKinsey \& Company. (2020). Consumer sentiment and behavior continue to reflect the uncertainty of the COVID-19 crisis. Retrieved from https://www.mckinsey.com/business-functions/marketingand-sales/our-insights/a-global-view-of-how-consumer-behavior-is-changing-amid-covid-19

McLean, G., \& Wilson, A. (2019). Shopping in the digital world: Examining customer engagement through augmented reality mobile applications. Computers in Human Behavior, 101, 210-224.

Narang, U., \& Shankar, V. (2019). Mobile Marketing 2.0: State of the Art and Research Agenda. In Marketing in a Digital World (Vol. 16, pp. 97-119). Emerald Publishing Limited.

Pamuru, V., Khern-am-nuai, W., \& Kannan, K.N. (2020). The impact of an augmented reality game on local businesses: A study of Pokémon go on restaurants. Information Systems Research (Forthcoming).

Pantano, E., Rese, A., \& Baier, D. (2017). Enhancing the online decision-making process by using augmented reality: A two country comparison of youth markets. Journal of Retailing and Consumer Services, 38, 81-95.

Papagiannis, H. (2017). Augmented Human: How Technology is Shaping the New Reality. O'Reilly Media.

Pappas, I.O., Pateli, A.G., Giannakos, M.N., \& Chrissikopoulos, V. (2014). Moderating effects of online shopping experience on customer satisfaction and repurchase intentions. International Journal of Retail \& Distribution Management.

Parise, S., Guinan, P.J., \& Kafka, R. (2016). Solving the crisis of immediacy: How digital technology can transform the customer experience. Business Horizons, 59(4), 411-420.

Paulo, M.M., Rita, P., Oliveira, T., \& Moro, S. (2018). Understanding mobile augmented reality adoption in a consumer context. Journal of Hospitality and Tourism Technology, 9(2), 142-157. doi:10.1108/JHTT-01-2017-0006

Piroozfar, P., Farr, E.R., Boseley, S., Essa, A., \& Jin, R. (2018). The application of Augmented Reality $(A R)$ in the Architecture Engineering and Construction (AEC) industry. Paper presented at the The Tenth International Conference on Construction in the 21st Century (CITC-10). 
Poushneh, A., \& Vasquez-Parraga, A.Z. (2017a). Customer dissatisfaction and satisfaction with Augmented Reality in shopping and entertainment. Journal of Consumer Satisfaction, Dissatisfaction \& Complaining Behavior, 30.

Poushneh, A., \& Vasquez-Parraga, A.Z. (2017b). Discernible impact of augmented reality on retail customer's experience, satisfaction and willingness to buy. Journal of Retailing and Consumer Services, 34, 229-234.

Ramírez-Correa, P., Rondán-Cataluña, F.J., Arenas-Gaitán, J., \& Martín-Velicia, F. (2019). Analysing the acceptation of online games in mobile devices: An application of UTAUT2. Journal of Retailing and Consumer Services, 50, 85-93.

Roxo, M.T., \& Brito, P.Q. (2019). Augmented Reality: What Motivates Late Millennials towards Fashion Mobile Apps? Paper presented at the Academy of Marketing Science World Marketing Congress.

Sarfaraz, J. (2017). Unified theory of acceptance and use of technology (Utaut) model-mobile banking. Journal of Internet Banking and Commerce, 22(3), 1-20.

Schapsis, C., \& Chiagouris, L. (2019). Outlining a New Approach to Study Mobile Marketing: Relevancy as a Primary Mediating Construct to Understand Mobile Advertising Effectiveness. Paper presented at the Proceedings of the 2019 5th International Conference on E-business and Mobile Commerce.

Scholz, J., \& Duffy, K. (2018). We ARe at home: How augmented reality reshapes mobile marketing and consumer-brand relationships. Journal of Retailing and Consumer Services, 44, 11-23.

Shaw, N., \& Sergueeva, K. (2019). The non-monetary benefits of mobile commerce: Extending UTAUT2 with perceived value. International Journal of Information Management, 45, 44-55.

Smith, S.M., Roster, C.A., Golden, L.L., \& Albaum, G.S. (2016). A multi-group analysis of online survey respondent data quality: Comparing a regular USA consumer panel to MTurk samples. Journal of Business Research, 69(8), 3139-3148. doi:https://doi.org/10.1016/j.jbusres.2015.12.002

Tak, P., \& Panwar, S. (2017). Using UTAUT 2 model to predict mobile app based shopping: Evidences from India. Journal of Indian Business Research.

Tamilmani, K., Rana, N.P., Dwivedi, Y., Sahu, G.P., \& Roderick, S. (2018). Exploring the Role of Price Value'for Understanding Consumer Adoption of Technology: A Review and Meta-analysis of UTAUT2 based Empirical Studies. Paper presented at the PACIS.

Tamilmani, K., Rana, N.P., \& Dwivedi, Y.K. (2018). Use of 'habit'is not a habit in understanding individual technology adoption: A review of UTAUT2 based empirical studies. Paper presented at the International Working Conference on Transfer and Diffusion of IT.

Tavolieri, J. (2019, December 12). Augmented Retail: The New Consumer Reality. Retrieved from https://www.nielsen.com/us/en/insights/article/2019/augmented-retail-the-new-consumer-reality

Testa, J., Maheshwari, S., \& Friedman, V. (2020, July 21). Which Clothing and Beauty Stores Have Closed? Retrieved from https://www.nytimes.com/2020/03/18/style/coronavirus-clothing-beautystores-closed.html

Van Krevelen, D., \& Poelman, R. (2010). A survey of augmented reality technologies, applications and limitations. International Journal of Virtual Reality, 9(2), 1-20.

Venkatesh, V., Morris, M.G., Davis, G.B., \& Davis, F.D. (2003). User acceptance of information technology: Toward a unified view. MIS Quarterly, pp. 425-478.

Venkatesh, V., Thong, J.Y., \& Xu, X. (2012). Consumer acceptance and use of information technology: Extending the unified theory of acceptance and use of technology. MIS Quarterly, pp. 157-178.

Von Itzstein, G.S., Billinghurst, M., Smith, R.T., \& Thomas, B.H. (2019). Augmented Reality Entertainment: Taking Gaming Out of the Box. In.

Wedel, M., Bigné, E., \& Zhang, J. (2020). Virtual and augmented reality: Advancing research in consumer marketing. International Journal of Research in Marketing, 37(3), 443-465.

Wiebach, N., \& Send, H. (2020). Augmented Reality Shopping Services-Key Factors Affecting Customer Evaluation and Acceptance. Journal of Marketing Development and Competitiveness, 14(4), 91100. 
Wu, T. (2017). Pokémon Go: Marketing implications for mobile video game. In Computing in Smart Toys (pp. 7-20). Springer.

Xiao, Z., Yun, W., \& Yueqing, L. (2019). The Tendency of Trust in A Distrustful Environment: The Mediation Role of Contextual Perceptions in eWOM. Journal of Marketing Development \& Competitiveness, 13(5), 46-64. doi:10.33423/jmdc.v13i5.2641

Yaoyuneyong, G., Foster, J., Johnson, E., \& Johnson, D. (2016). Augmented reality marketing: Consumer preferences and attitudes toward hypermedia print ads. Journal of Interactive Advertising, 16(1), $16-30$.

Yung, R., \& Khoo-Lattimore, C. (2019). New realities: A systematic Literature review on virtual reality and augmented reality in tourism research. Current Issues in Tourism, 22(17), 2056-2081.

Zhang, X., \& Barnes, C. (2019). The Suspicious Factors in Electronic Word-of-Mouth Communication. Journal of Marketing Development \& Competitiveness, 13(2), 101-115. doi:10.33423/jmdc.v13i2.2015

Zhou, F., Duh, H.B-L., \& Billinghurst, M. (2008). Trends in augmented reality tracking, interaction and display: A review of ten years of ISMAR. Paper presented at the 2008 7th IEEE/ACM International Symposium on Mixed and Augmented Reality.

\section{APPENDIX}

\section{TABLE 1}

DEMOGRAPHICS OF THE SAMPLE

\begin{tabular}{|r|l|}
\hline \multicolumn{2}{|c|}{ Variables $n=213$} \\
\hline Gender & Female $\mathrm{n}=108$ \\
& Male $\mathrm{n}=105$ \\
\hline Age & $18-21 \mathrm{n}=7$ \\
& $22-25 \mathrm{n}=29$ \\
& $26-29 \mathrm{n}=31$ \\
& $30-33 \mathrm{n}=31$ \\
& $34-37 \mathrm{n}=38$ \\
& $38-41 \mathrm{n}=24$ \\
& $42-45 \mathrm{n}=12$ \\
& $46-50 \mathrm{n}=14$ \\
& $>50 \mathrm{n}=27$ \\
\hline Education & Less than High School $\mathrm{n}=1$ \\
& High School graduate $\mathrm{n}=21$ \\
& Some college $\mathrm{n}=42$ \\
& 2-year degree $\mathrm{n}=26$ \\
& 4-year degree $\mathrm{n}=95$ \\
& Professional degree $\mathrm{n}=26$ \\
& Doctorate $\mathrm{n}=2$ \\
\hline & \\
\hline &
\end{tabular}


TABLE 2

\section{EXPLORATORY FACTOR ANALYSIS}

\begin{tabular}{|c|c|c|c|}
\hline Construct & Description & $\alpha$ & $\begin{array}{l}\text { Factor } \\
\text { Loading }\end{array}$ \\
\hline \multirow{5}{*}{$\begin{array}{l}\text { Performance } \\
\text { Expectancy } \\
\text { PE }\end{array}$} & $\begin{array}{l}\text { I find the shoes AR app useful for my footwear online shopping } \\
\text { activities }\end{array}$ & \multirow{5}{*}{$\begin{array}{c}.90 \\
9\end{array}$} & 0.737 \\
\hline & $\begin{array}{l}\text { When buying footwear online, the shoes AR app makes } \\
\text { shopping easier }\end{array}$ & & 0.804 \\
\hline & $\begin{array}{l}\text { Using this type of shoes' AR App increases my chances to make } \\
\text { a better decision when purchasing footwear online }\end{array}$ & & 0.772 \\
\hline & $\begin{array}{l}\text { Using this type of shoes' AR App enables me to accomplish } \\
\text { shopping tasks more quickly }\end{array}$ & & 0.783 \\
\hline & $\begin{array}{l}\text { When buying shoes online, the shoes AR app makes my } \\
\text { shopping more effective }\end{array}$ & & 0.819 \\
\hline \multirow{3}{*}{$\begin{array}{l}\text { Hedonic } \\
\text { Motivation } \\
\text { HM }\end{array}$} & Using the shoes' AR app is fun & \multirow{3}{*}{$\begin{array}{c}.88 \\
3\end{array}$} & 0.815 \\
\hline & The AR content makes the shoes' AR app enjoyable & & 0.766 \\
\hline & Using the shoes' AR app is very entertaining & & 0.772 \\
\hline \multirow{3}{*}{$\begin{array}{c}\text { Habit } \\
\mathbf{H}\end{array}$} & Using AR or face filters features in apps is a habit for me & \multirow{3}{*}{$\begin{array}{c}.89 \\
6\end{array}$} & 0.902 \\
\hline & AR or face filters features in apps are very important to me & & 0.851 \\
\hline & Using AR or face filters in apps has become natural to me & & 0.85 \\
\hline \multirow{4}{*}{$\begin{array}{c}\text { Effort } \\
\text { Expectancy } \\
\text { EE }\end{array}$} & $\begin{array}{l}\text { Learning how to use the AR functionality on this app is easy for } \\
\text { me }\end{array}$ & \multirow{4}{*}{$\begin{array}{c}.84 \\
8\end{array}$} & 0.802 \\
\hline & It was clear how to use the AR features of the app & & 0.755 \\
\hline & I find it easy to use apps with AR features & & 0.819 \\
\hline & $\begin{array}{l}\text { It is easy for me to become skillful at using the AR feature of } \\
\text { the app }\end{array}$ & & 0.818 \\
\hline \multirow{4}{*}{$\begin{array}{c}\text { Innovativene } \\
\text { ss } \\
\text { I }\end{array}$} & $\begin{array}{l}\text { It is easy for me to become skillful at using the AR feature of } \\
\text { the app }\end{array}$ & \multirow{4}{*}{$\begin{array}{c}.83 \\
9\end{array}$} & 0.818 \\
\hline & $\begin{array}{l}\text { If I hear about a new app, I will look for ways to experiment } \\
\text { with it }\end{array}$ & & 0.757 \\
\hline & Among my peers, I'm usually the first to try new apps & & 0.840 \\
\hline & I like to experiment with new apps & & 0.804 \\
\hline \multirow{4}{*}{$\begin{array}{c}\text { Behavioral } \\
\text { Intention } \\
\text { BI }\end{array}$} & $\begin{array}{l}\text { Given a chance, I intend to use the AR features of an app when } \\
\text { e-shopping }\end{array}$ & \multirow{4}{*}{$\begin{array}{c}91 \\
7\end{array}$} & 0.721 \\
\hline & I plan to continue to use these kinds of AR features in the future & & 0.736 \\
\hline & I have the intention to use AR features when e-shopping & & 0.729 \\
\hline & I will always try to use the AR features when e-shopping & & 0.747 \\
\hline
\end{tabular}




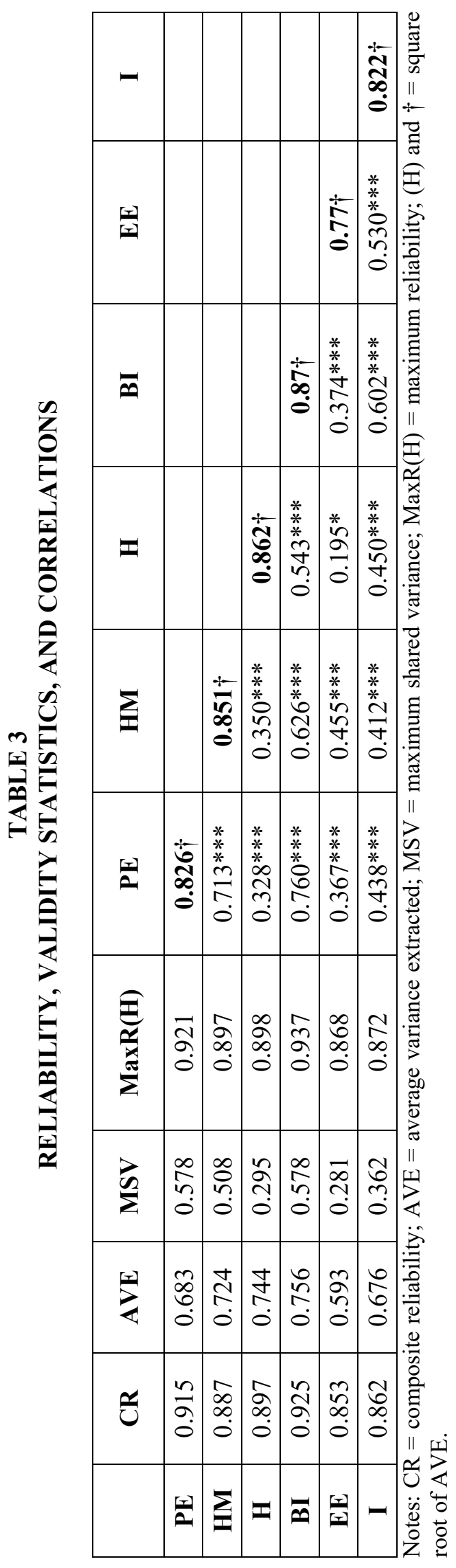

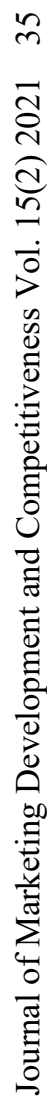


TABLE 4

FIT INDICES OF CFA MODEL

\begin{tabular}{|l|l|l|l|l|}
\hline Measure & Abbr. & Estimate & Threshold & Interpretation \\
\hline Chi-square/df & CMIN/DF & 1.732 & Between 1 and 3 & Excellent \\
\hline Comparative Fit Index & CFI & 0.958 & $>0.95$ & Excellent \\
\hline $\begin{array}{l}\text { Standardized Root Mean } \\
\text { Square Residual }\end{array}$ & SRMR & 0.049 & $<0.08$ & Excellent \\
\hline $\begin{array}{l}\text { Root Mean-Square Error of } \\
\text { Approximation }\end{array}$ & RMSEA & 0.059 & $<0.06$ & Excellent \\
\hline p-value of the null hypothesis & PClose & 0.086 & $>0.05$ & Excellent \\
\hline
\end{tabular}

TABLE 5

STANDARDIZED PATH COEFFICIENTS

\begin{tabular}{|l|l|l|l|l|}
\hline Predictor & Outcome & Std Beta & $\mathbf{p}$ & Remarks \\
\hline $\begin{array}{l}\text { Performance } \\
\text { Expectancy } \\
\text { PE }\end{array}$ & $\begin{array}{l}\text { Behavioral Intention } \\
\text { BI }\end{array}$ & .530 & .000 & H1 Supported \\
\hline $\begin{array}{l}\text { Effort Expectancy } \\
\text { EE }\end{array}$ & $\begin{array}{l}\text { Behavioral Intention } \\
\text { BI }\end{array}$ & -0.035 & .572 & $\begin{array}{l}\text { H2 Not } \\
\text { Supported }\end{array}$ \\
\hline $\begin{array}{l}\text { Hedonic Motivation } \\
\text { HM }\end{array}$ & $\begin{array}{l}\text { Behavioral Intention } \\
\text { BI }\end{array}$ & 0.079 & .298 & $\begin{array}{l}\text { H3 Not } \\
\text { Supported }\end{array}$ \\
\hline $\begin{array}{l}\text { Habit } \\
\text { H }\end{array}$ & $\begin{array}{l}\text { Behavioral Intention } \\
\text { BI }\end{array}$ & .236 & .000 & H4 Supported \\
\hline $\begin{array}{l}\text { Innovativeness } \\
\text { I }\end{array}$ & $\begin{array}{l}\text { Behavioral Intention } \\
\text { BI }\end{array}$ & .249 & .000 & H5 Supported \\
\hline
\end{tabular}

